\title{
Spatial fragmentation and self-organisation: a negative relationship in Brazilian metropolises
}

\author{
Fragmentação espacial e autogovernação: uma relação negativa nas \\ metrópoles brasileiras
}

Igor Tempels Moreno Pessoa[a] (1)

[a] Faculty of Architecture and the Built Environment, Building 8, Julianalaan, Delft, The Netherlands

How to cite: Pessoa, I. T. M. (2019). Spatial fragmentation and self-organisation: a negative relation in Brazilian metropolises. urbe. Revista Brasileira de Gestão Urbana, v. 11, e20180002. https://doi.org/10.1590/21753369.011.e20180002

\begin{abstract}
While Brazilian metropolises are spatially fragmented, at the same time they have abundant bottom-up, spontaneous, self-organised initiatives that usually emerge as a response to weak or negligent public authorities. Both phenomena are influencing Brazilian metropolises, but we do not know how they influence each other. This paper aims to answer the question: To what extent does spatial fragmentation influence self-organised initiatives? The article is based on analysis of data collected in the municipality of São Paulo. It first develops a theoretical reflection on both concepts, fragmentation and self-organisation, followed by an outline of the methods and analysis. The work is based on a series of in-depth interviews and field observations of six self-organised initiatives. The results show that the spatial fragmentation pattern observed in São Paulo is defined by a strongly polarised urban structure that heavily influences the operation of self-organised initiatives. This imposes a limitation on the work area of self-organised initiatives. The study indicates that the relationship between spatial fragmentation and self-organised initiatives, however, is not straightforward. Moreover, spatial fragmentation hinders the expansion of the work of self-organised initiatives.
\end{abstract}

Keywords: Spatial fragmentation. Self-organisation. Self-organised initiatives. Self-governance.

\section{Resumo}

Ao mesmo tempo em que as metrópoles brasileiras são fragmentadas espacialmente, elas possuem abundantes iniciativas populares, espontâneas e autogovernáveis que surgem normalmente em resposta a um ente público pouco presente ou negligente. Este artigo tem como objetivo responder a seguinte pergunta: até que ponto a fragmentação espacial influencia iniciativas autogovernáveis? Este trabalho é baseado na análise de dados coletados na cidade de São Paulo. Primeiramente, uma reflexão teórica sobre os dois conceitos é desenvolvida, seguida pela apresentação dos métodos usados e a análise em si. A pesquisa é baseada em uma série de entrevistas e observações de campo de seis iniciativas autogovernáveis. Os resultados mostram que o padrão de fragmentação espacial observado na cidade de São Paulo é definido por uma forte estrutura urbana polarizada que influencia fortemente a operação das

ITMO is postdoctoral researcher, TU Delft, Urbanism - Research for the Built Environment, e-mail: i.pessoa@tudelft.nl 
iniciativas autogovernáveis, pois suas áreas de trabalho acabam sendo limitadas. $O$ estudo aponta que a relação entre fragmentação espacial e iniciativas autogovernáveis não é clara e que a fragmentação espacial está prejudicando a expansão da atuação das organizações autogovernáveis.

Palavras-chave: Fragmentação espacial. Auto-organização. Organizações autogovernáveis. Autogovernação.

\section{Introduction}

Since the 1960s, urbanisation in Brazil has been changing the country from a predominantly rural society, with less than half the population living in cities in 1960, to a highly urbanised society, with an $84.5 \%$ urbanisation rate in 2010 (IBGE, 2015b). This phenomenon was accompanied by a population increase of $270 \%$ (IBGE, 2015a), resulting in the massive growth of urban population. This process has also been accompanied by intensive opportunity-led development, where conventional urban planning tools were unable to cope, and cities being built according to a strong market logic. The result in contemporary Brazilian metropolises is a fragmented and unequal urban environment.

Public urban policies have not been able to respond effectively to this challenge. Conventional urban planning tools, such as zoning strategies and top-down master plans, have successively failed to provide services, and even affordable housing in the formal sector, as needed by the population. Nevertheless, while these conventional urban planning tools were not successful, Brazilian metropolises have become fertile ground for bottom-up, self-organised initiatives. These initiatives commonly emerge in contexts where the public authorities would traditionally be the leading actor, such as in improving public spaces, providing social services or even renewing urban infrastructure. As can be observed in some of the cases analysed below, the initiatives emerged from a popular need that was not being effectively addressed by state institutions.

Self-organised initiatives rely on a social connection between members to function effectively; moreover, in Brazil, they need to operate in a very fragmented urban environment. This paper delves deeper into the relationship between spatial fragmentation and these self-organised initiatives. In this regard, it is important to understand the challenges and difficulties that spatial fragmentation generates for self-organised initiatives.

According to Caldeira (2000), the city of São Paulo is an extreme example of spatial fragmentation, which creates an inefficient urban system characterised by rigidity and violence. While a high degree of physical fragmentation is created by walls, spatial fragmentation is not only based on physical barriers but also on socioeconomic differences. In theory, creating physical connections between urban spaces would be an example of a 'good' planning strategy to promote social connectivity and therefore better conditions to generate self-organised initiatives. Nevertheless, physical connection does not necessarily promote social connection between diverse groups or individuals. There may be other factors influencing this phenomenon apart from the simple connection of spaces. As Sabatini \& Salcedo (2007) suggest, in some specific contexts, the development of gated communities and the physical barriers surrounding them can, to some extent, create a social connection between residents and non-residents of such communities. The relationship between physical connection and social connection is thus not that straightforward.

Acknowledging that self-organisation is highly influenced by local conditions, this paper addresses the relationship between spatial fragmentation and some self-organised initiatives in the city of São Paulo in detail. More specifically, it asks the question: To what extent does spatial fragmentation influence self-organised initiatives? This question will be addressed using an urban policy lens, which means that the concepts of spatial fragmentation and self-organisation are to be understood in a broader urban context that goes beyond mere urban planning. The aim of this article is to develop the theoretical debate around the two concepts and elaborate on how spatial fragmentation could have a negative influence on self-organised initiatives. Furthermore, the article contributes to the self-organisation literature by relating it to that on spatial fragmentation. 


\section{Theory}

\section{What does spatial fragmentation mean?}

The notion of spatial fragmentation used in urban studies refers mainly to two other fields of knowledge. The first one is Landscape Ecology where spatial fragmentation is seen more related to morphology. It is given a greater focus on the physical rupture of space. This view is present in the work of Dramstad et al. (1996), where the authors develop on principles related to fragmentation such as patches, edges and corridors; Lister et al. (2015) focus more on the environmental impact of these physical interruptions; while Angel et al. (2012) develop their research on satellite images specially connected to urban sprawl. The second view of spatial fragmentation is based on critical Geography and takes into account the social limitations created by this physical division of the space. In this study, the concept of spatial fragmentation is aligned with this second view of spatial fragmentation, especially related to the work developed by Milton Santos about the city of São Paulo.

Santos' notion of spatial fragmentation refers to an extremely unequal spatial pattern in the built environment. For example, the physical built environment may develop in different forms, in what Santos calls as un 'uneven accumulation of times'. This notion of the accumulation of times refers to the development of very distinct spatial structures within the same built environment (Santos \& Dias, 1982). In other words, development does not occur in an equal way in all areas. Within the same urban context, for example, it is possible to observe people living in modern skyscrapers, while others live in dwellings that are reminiscent of sixteenth-century infrastructure. Santos analyses the spatial organisation of São Paulo (2009) as a collection of different fragments. This approach already served as a basis for other researches, like for example the study from Balbo and Navez-Bouchanine about Rabat-Salé in Morocco. Based on Santo's perspective the authors define fragmentation as a characteristic of most cities in developing countries, which contrasts with the orderly space of the developed Global North. In the words of Balbo and Navez-Bouchanine:

[...] the city of the developing countries shows a distinct spatial pattern characterised by the variety of the physical environment or the fragmentation of urban space. From an aerial view, most Third World cities appear as a complex mosaic where the various pieces are assembled according to a logic entirely different from that of the rational and efficient industrial city model. [...] In this paper we consider fragmentation to be the sum of autonomous elements (Balbo \& Navez-Bouchanine, 1995, p. 573)

Based on Balbo and Navez-Bouchanine, identifying fragmentation depends on the autonomous capacity of various areas of a city. In this sense, areas with a high number of slums and gated communities can be classified as fragmented systems. In this article, the term 'fragmentation' refers not only to the difference in the spatial characteristics of distinct areas of a city, but also to the low degree of integration between the residents of these areas. The framework of Sabatini and Salcedo is used as a reference to analyse the level of integration. Spatial fragmentation, therefore, involves more than just diversity within an urban system.

In a general view, the city of São Paulo is described by Milton Santos as a 'fragmented corporative metropolis' (translation by the author from Portuguese 'metrópole corporativa fragmentada') (2009). In addition to being led by the market, which is the corporative aspect, fragmentation in São Paulo is constrained by the polarised structure of the city, where jobs and services are concentrated in the city centre. The population living in the suburbs on the periphery have less access to these jobs and services due to an inefficient public transport network and a lack of financial means. According to the author, this centre/periphery dichotomy is the main underlying force of fragmentation in São Paulo (Santos, 2009), a strong reason for social disconnection. 


\section{Distinct fragmentation patterns}

The fragmentation dynamics of São Paulo are linked to strong polarisation, which can be demonstrated by looking at different indicators. The concept of porosity, for example, is helpful to illustrate this. 'Porosity' is a metaphor for urban areas with spatial discontinuities, such as brownfield areas, empty spaces and disconnected neighbourhoods. A porosity index (Pessoa et al., 2016) is used to measure and understand the different types of porosity in the Brazilian context. In the case of São Paulo, as seen in Table 1, porosity is mainly created by strong economic growth and the presence of informal settlements.

Table 1 - Porosity index of São Paulo

\begin{tabular}{|c|c|c|c|c|c|c|c|c|}
\hline Metropolis & $\begin{array}{c}\text { Population } \\
\text { growth } \\
(2000-2010)\end{array}$ & $\begin{array}{c}\text { Real GDP } \\
\text { growth per } \\
\text { head (2000- } \\
2010)\end{array}$ & $\begin{array}{c}\text { Dwellings } \\
\text { growth } \\
(2000-2010)\end{array}$ & $\begin{array}{l}\text { Growth as } \\
\text { input for } \\
\text { porosity }\end{array}$ & $\begin{array}{l}\text { Houses in } \\
\text { gated } \\
\text { communities }\end{array}$ & $\begin{array}{l}\text { Houses in } \\
\text { slums }\end{array}$ & $\begin{array}{c}\text { Dwellings } \\
\text { without } \\
\text { street/ } \\
\text { number } \\
\text { identification }\end{array}$ & $\begin{array}{l}\text { Output } \\
\text { porosity }\end{array}$ \\
\hline & $\mathbf{a}$ & b & C & {$[a+b+c] / 3$} & c & d & e & {$[c+d+e] / 3$} \\
\hline São Paulo & 0.08 & 0.28 & 0.20 & 0.16 & 0.01 & 0.10 & 0.06 & 0.06 \\
\hline
\end{tabular}

Source: Pessoa et al. (2016)

A large share of informal settlements in the provision of housing is a strong indicator of fragmentation in São Paulo. The Brazilian Institute of Geography and Statistics (IBGE) uses the term 'subnormal agglomeration' ('aglomerado subnormal') to define those areas that are popularly known as favelas (slums), and introduced the following definition in the 2010 census:

[...] a group made up of 51 dwellings or more that have no property titles and have at least one of the following characteristics: irregularity of access routes, the shape or the size of the plots, and a lack of essential public services - for example, no garbage collection, sewage network, water network, electricity or street lighting (IBGE, 2010).

The term 'informal settlement' does not mean that there are no social structures or any kind of order in these areas. The areas identified by IBGE as informal just follow a different legal and spatial logic than the one recognised by the state. Despite the limitations of the terminology, the term informal settlement used in this article is based on the definition given by IBGE. While IBGE's definition focuses on spatial and physical aspects, which are insufficient to understand the dynamics of social inequality, power struggles or other societal challenges (Kovacic \& Giampietro, 2016), it is important to explore this definition in detail in order to understand how informal settlements relate to fragmentation. IBGE's definition mentions groups of 51 dwellings or more, without property titles. This characterises a collective structure outside the government legal framework. The group aspect is emphasised, as the definition focuses on collective capacity and ignores the possibility of individual dwellings without property titles. 

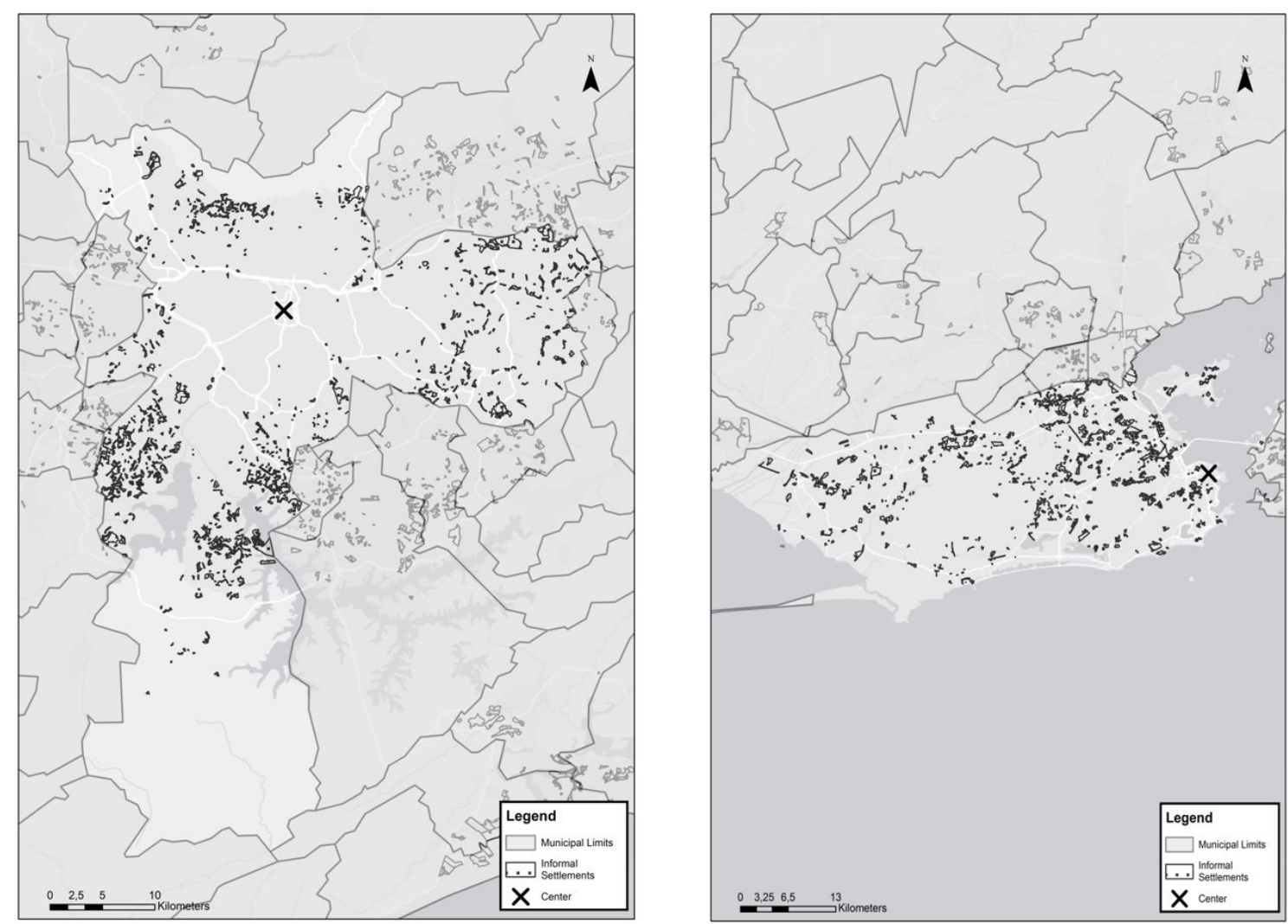

Figure 1 - Informal Settlements in São Paulo (left) and in Rio de Janeiro (right). Source: produced by the author with data on subnormal agglomerates from IBGE.

This is not only a collective deviation from the formal urban structure, but also a strong sign of a parallel legal framework. The maps depict the location of informal settlements in São Paulo and Rio de Janeiro (Figure 1). The map of São Paulo shows a strong polarised structure, with informal settlements located on the periphery, while the city centre has almost no informal settlements. Comparing São Paulo with Rio de Janeiro, Figure 1 shows different structures related to spatial fragmentation. While São Paulo has a clearly polarised structure, with the city centre being one main pole, Rio de Janeiro has a more homogenous structure, with informal settlements distributed in a rather random pattern throughout the entire municipality.

The polarisation structure is not restricted to informal settlements in São Paulo, as gated communities are another indicator of fragmentation, because they also have the autonomous capacity mentioned by Balbo \& Navez-Bouchanine (1995). This can be seen in research by D'Ottaviano (2008), which confirmed the polar structure of the development of gated communities in São Paulo. Moreover, the IBEU data shows this polarised structure, with more affluent areas concentrated in the city centre and less affluent areas on the periphery (Ribeiro \& Ribeiro, 2013). Historically, the city invested in individual modes of transportation, with the inhabitants of the suburbs largely dependent on cars or on a very inefficient public transport system. Santos shows that due to factors such as limited financial capacity or a poor transportation system, a fragmented structure was created, where the population outside the city centre was ultimately restricted to the vicinity. Urban fragmentation in São Paulo is manifest in this extreme polarisation.

\section{What kind of self-organisation?}

A second key concept concerns self-organisation. There are two main interpretations of 'self-organisation' in urban studies. The first relates to complexity science (Ashby, 1947; Eigen, 1971; Foerster \& Zoepf, 1962; Haken, 1983), while the second is used in governance studies (Dam et al., 2009; Kotus \& Hławka, 
2010; Nunbogu et al., 2017; Wunsch, 2013). Although both fields use the term 'self-organisation' and the definitions have some similarities, they are fundamentally different. Ward Rauws (2016) developed a framework to distinguish the two, in an attempt to avoid possible confusion. While self-organisation as seen through a complexity science lens focuses on the emergence of spontaneous urban patterns from individual local interactions (Heylighen, 2008; Portugali, 1999), in governance studies the focus is on processes of self-governance, where citizens take the lead from the government and act in a kind of bottom-up, grassroots, 'do-it-yourself' urbanism (Kee \& Miazzo, 2014; Newman et al., 2008). The later interpretation, aligned with governance studies, is used in this article.

According to Rauws, self-organisation considered through a governance studies perspective has four main characteristics that clearly distinguish it from the complexity science perspective: there is internal coordination, where members develop a participation and decision-making process; actions are undertaken with a collective intent, where a common goal, for example the renewal of a public space, is the aim; a change in the urban environment is the result of this deliberate action designed to achieve this common goal; and the transformation of the urban system is to some extent predictable (Rauws, 2016). In summary, the initiatives rely on an internal process of coordination, have a common goal, bring people together to act to achieve this goal and the result of this change is relatively predictable. These self-organised initiatives work independently from the government (Dam et al., 2009; Schmidt-Thome et al., 2014; Swyngedouw \& Moulaert, 2010) and usually bypassing the established networks of governance and institutions (Lydon \& Garcia, 2015).

The self-organised initiatives studied here share the above-mentioned criteria. Firstly, they are all managed by a civil society group, which means that they are not externally controlled by any government body or private enterprise. This does not mean that public institutions have not influenced the initiatives, but rather that the initiatives are independent and act with a bottom-up logic. The relationship of the initiatives with the private sector may vary, with some of them receiving support from private companies. This occurs more often with initiatives that started as an informal collective but then developed into a formal association or NGO, which allows companies to financially contribute to them. Secondly, they do not aim for financial gain for a specific group or person, but are focused on solving collective problems. Thus, they concentrate on the collective aspect mentioned by Wunsch (2013). There is always a factor of common concern in the initiatives that goes beyond individual financial interest. Furthermore, they focus their work on an urban challenge which normally would be tackled by public authorities (Tonkens, 2008). The initiatives analysed here addressed issues that are traditionally dealt with by public agencies, focusing on urban challenges - for example, the renewal of public spaces.

The Organismo Parque Augusta (OPA) can serve to illustrate the self-organised initiatives studied. They support the development of green areas in the city of São Paulo and was created specifically to keep the Augusta park open. The park is located on private land, which generated several conflicts of interest on the past 5 years. As stated on an online page from the group, the OPA is:

A self-managed, horizontal and heterogeneous movement. It is not represented by any group or entity officially instituted. It organizes itself based on public assemblies, meeting and working groups, direct actions on the street and in the internet. It is open to the participation of whoever is interested in supporting its cause: the Augusta park 100\% public, free from any real estate speculation agent and with popular management (OPA, 2019).

Due to the openness of the initiative, it is hard to estimate how many people take part on it. Nevertheless, the OPA webpage states that a total of 250 different people signed their guestbook on their first 28 public assemblies. They have more than 25.000 people following their actions on Facebook, where they published 31 different events organised by them in the year of 2017 . These events are aimed mainly to improve the park and to coordinate and debate their actions. The group is extremely active and continued to have meetings even when public authorities obstructed their access to the park. Even though initiatives have different agendas, they all were extremely persistent to push for their agendas and had a horizontal and open organizational structure. 


\section{Methods}

The research started with a literature review on spatial fragmentation and self-organisation aforementioned. This initial section also considered the development of the concepts, the current debate and the application of both concepts in the Brazilian context. The research used different sources of data. We accessed data from IBGE about the location of informal settlements. The data were used in ArcGIS to develop maps and visualise the fragmented structure of the city. These maps (Figure 1) confirmed the fragmentation dynamics of São Paulo as claimed by Milton Santos, with informal settlements found to be located on the periphery, while the city centre of São Paulo had almost none.

A qualitative strategy was developed to understand how this fragmented and polarised structure is currently affecting self-organised initiatives in the city of São Paulo. A preliminary online scan of social media and related websites was undertaken to look for initiatives, which indicated that they were concentrated in the city centre. The researcher's professional network was also used to find key participants in these initiatives and start a snowball process. This process started with soliciting planners and researchers working with self-organising initiatives for key contacts in these initiatives to start the snowballing. The snowball strategy worked well, but also demonstrated a relative limitation, as it did not extend to initiatives based in peripheral neighbourhoods. The initiatives contacted were limited to a network that only extended to the city centre region. Nevertheless, this did not hinder the research and it was still possible to investigate how this polarised structure influenced these initiatives in the city centre; in other words, the kind of relationship that self-organised initiatives in the city centre have with the peripheral neighbourhoods and their residents.

Ten semi-structured in-depth interviews were conducted in São Paulo with members of these organisations, as well as academics and public servants working at the municipality dealing with these initiatives. The interviews were conducted in July 2016 and took place at the office or meeting place of the initiatives, in public spaces or in cafés. The search for initiatives that would fit the criteria mentioned above was relatively easy; however, it turned out to be challenging to find a representative willing to give an interview. As will be further explained in the analysis, there was a common concern of the interviewees not to be regarded as the leader of the initiative. In São Paulo, as shown in Table 2, contact was made with six initiatives:

Table 2 - Initiatives contacted in São Paulo

\begin{tabular}{|c|c|c|c|}
\hline Initiative & Contact & Actions & Area of work \\
\hline $\begin{array}{l}\text { Terreyro } \\
\text { Coreográfico }\end{array}$ & $\begin{array}{l}\text { In-depth } \\
\text { interview }\end{array}$ & $\begin{array}{c}\text { Renewal of public spaces under } \\
\text { viaducts through the organisation of } \\
\text { dance-related events. }\end{array}$ & Expanded city centre \\
\hline Bela Rua & $\begin{array}{l}\text { In-depth } \\
\text { interview }\end{array}$ & Renewal of public spaces. & Expanded city centre \\
\hline Cidade Ativa & $\begin{array}{l}\text { In-depth } \\
\text { interview }\end{array}$ & $\begin{array}{l}\text { Develop urban interventions to } \\
\text { promote mobility on foot. }\end{array}$ & $\begin{array}{l}\text { Expanded city centre and occasional } \\
\text { work in the periphery }\end{array}$ \\
\hline $\begin{array}{l}\text { Organismo } \\
\text { Parque } \\
\text { Augusta }\end{array}$ & $\begin{array}{l}\text { In-depth } \\
\text { interview and } \\
\text { social media } \\
\text { observation }\end{array}$ & $\begin{array}{l}\text { Reclaim and manage the Parque } \\
\text { Augusta, a public park that is located } \\
\text { on private land and has been } \\
\text { targeted by real estate developers. } \\
\text { Different urban interventions to raise }\end{array}$ & $\begin{array}{c}\text { City Centre, but mainly in Parque } \\
\text { Augusta }\end{array}$ \\
\hline $\begin{array}{l}\text { Colaboratório - } \\
\text { Lab Bijari }\end{array}$ & $\begin{array}{l}\text { In-depth } \\
\text { interview }\end{array}$ & $\begin{array}{l}\text { awareness of how urban space is } \\
\text { being used; for example, highlighting } \\
\text { where empty buildings are located. }\end{array}$ & $\begin{array}{l}\text { Expanded city centre and occasional } \\
\text { work in the periphery }\end{array}$ \\
\hline $\begin{array}{l}\text { A Batata } \\
\text { Precisa de } \\
\text { Você }\end{array}$ & $\begin{array}{l}\text { Social media } \\
\text { and field } \\
\text { observation }\end{array}$ & $\begin{array}{c}\text { Renewal of the Largo da Batata, a } \\
\text { public square located in the Pinheiros } \\
\text { neighbourhood. }\end{array}$ & $\begin{array}{c}\text { Expanded city centre, but mainly in } \\
\text { the Largo da Batata }\end{array}$ \\
\hline
\end{tabular}

Source: produced by the author. 
The interviews were audio-recorded and analysed later with Atlas.ti software, where themes like connection with the neighbourhood, location of the initiatives, work in the periphery, communication between members, ties with the space of the intervention, and social connection with local residents were addressed. Field observations during physical meetings and participation in online groups of these initiatives also provided insights during the analysis.

\section{Spatial fragmentation and self-organised initiatives in São Paulo}

Self-organised initiatives rely on the capacity to communicate and integrate the wishes of their members. To better understand the level of social integration between the participants in self-organised initiatives, the research used the framework developed by Sabatini \& Salcedo (2007) as a reference, which defines three levels of integration: functional, symbolic and community. Functional integration is based on power and economic relations, and can be measured, for example, by the level of participation of the poor in the market, in the democratic process and in their access to services and urban facilities. Symbolic integration is related to the sense of belonging to the place where one lives. While community integration refers to:

[...] the formation of social ties that go beyond simple functional exchange. It is expressed in friendship, solidarity networks, and even familial relations. Community integration requires people to recognize and be recognized by the 'other' as an equal with whom it is possible to surmount the borders of privacy. Community means intimacy and complicity (Sabatini \& Salcedo, 2007, p. 589).

Nevertheless, it is challenging to deal with public space in an urban environment that exhibits striking inequalities. As mentioned by a member of Organismo Parque Augusta, when dealing with public spaces, you also have to deal with the problems of the city as a whole.

Because it is very different from squatting a house or an occupation aiming for housing. In a public park occupation, there is the idea of a place without ownership [...] another relationship. It is a collective relationship between the people there in a common space. It was very interesting. [...] the area was kept open 24 hours a day for 47 days, and we faced the complex challenges of the city itself. [...] It was a rich experience, because you could see there the relationship between people from different social classes came out (Member of Organismo Parque Augusta).

The striking spatial fragmentation of the Brazilian urban environment creates a greater challenge to the integration of inhabitants into the space in which they live. There are not only physical barriers but also financial inequalities, which make it more difficult to connect residents and the built environment. Without disregarding the complexity of social relationships in the metropolitan areas of Brazil, based on the three levels of social integration presented, it becomes clear that the metropolises with a high degree of inequality and spatial fragmentation actually exhibit more functional integration. Residents from informal settlements and residents from gated communities reveal functional integration, for example, when gated communities rely on the workforce of residents from informal settlements to do low-skill tasks. Villaça (2011) has already pointed out the negative impact of inequality on the metropolitan dynamic of São Paulo.

As argued above, due to the lack of capacity of the government to adequately respond to or manage the complex metropolitan environment (Maricato, 2011), Brazilian metropolises have become fertile ground for bottom-up initiatives, where civil society has taken on a major role, not only putting forward its demands but also implementing them. From the renewal of public spaces to the construction of urban infrastructure, self-organised initiatives have had an important role in the urban development of Brazilian cities. This is no different in São Paulo. Moreover, due to the massive scale of the city, many self-organised initiatives have emerged as a solution to different urban challenges. The initiatives analysed here were all, to some extent, working with the renewal of public spaces. Some of them undertook more ephemeral activities, such as social events in marginalised or abandoned spaces, while others focused on more long-term spatial interventions. While 
using different strategies, they all aimed for the improvement of public space and the wellbeing of the local inhabitants. As the aim here is to see how these active initiatives operated in a fragmented city and not how they emerged, all of the initiatives included in the research were already established and relatively successful, insofar as they have already produced concrete outcomes.

A common characteristic of these initiatives is to have a horizontal structure. This generates a model where there is no formal leadership. This lack of a clear leadership, which, as we suggested above, results in individual members being concerned that they will be seen as the voice of their respective initiative. During the interviews, it was common for interviewees to make a disclaimer that they should not be interpreted as speaking on behalf of the initiative. Although this matter was not explicitly addressed in the interview, some interviewees stated several times that their account should only be understood as their personal perspective and not as an opinion shared by the whole group (it should be noted, however, that interviewees coming from the public sector did not express this particular concern). This issue was raised by the 3 out of 6 interviewees. It was mentioned, for example, by an interviewee referring to how it was problematic not only to develop the initiative's common discourse, but also how to communicate it to the public authorities.

[...] I think that initiatives don't want to have a spokesperson [...] I think we have more of a lexical challenge [...] how do you say something that the regional mayor, a life-time bureaucrat, will listen to, will understand you [...] but I had to do this work [...] try to understand what were the problematic questions in the initiative and try to translate them in a way that a public servant would understand [...] (Member of the Terreyro Coreográfico).

One initiative that became well known for redeveloping a famous square in São Paulo, for example, was clearly initiated and led by one individual; however, due to what seems to be the result of this fear of being labelled the head of the initiative, it was not possible to interview this person. Instead, the researcher was invited to participate in an open meeting with them, in which field observations were made.

In order for these groups to operate without a clear hierarchy, it is imperative to have an effective communication process. Evidently, these interactions do not occur in a vacuum; even without an institutionalised hierarchy, social aspects such as gender, race, wealth and education definitely play a role in the internal dynamics of initiatives, as they do in Brazilian society generally. Nevertheless, the effective communication capacity of the initiatives was confirmed in the field observations and mentioned in all interviews. Most initiatives use Facebook groups to start a discussion, schedule meetings, define an agenda, create common documents and promote events. As one of the interviewees stated, the new social media technology made it possible to bring together people who had the desire to start an initiative:

[...] technology allowed this fit, they wouldn't be able to communicate and access each other so quickly if not for social media [...] now it seems that they know each other even better (Public servant from the Municipality of São Paulo).

It is worth noting that sometimes even if someone already had a strong connection with the local context and knew about the initiative, it was only after contact on social media that they became involved in the initiative. The capacity of social media to attract an online user to become part of a physical movement proved to be an important aspect for recruiting members and it was mentioned in 3 interviews.

I saw the problem of the 'Parque Augusta', which was an area that I had known about since 2002 [...] I knew that there was a local movement to protect that area [...] I had even spoken to people to understand what the situation was [...] but I made contact after a call for help on Facebook from this local group, because companies were advancing in their attempt to get a development project approved [...] at the same time, a lot of meetings started to take place in the park [...] (Member of Organismo Parque Augusta). 
All of the initiatives intensively used social media as a communication tool. However, even initiatives that relied heavily on digital interfaces also had physical meetings on a regular basis. Thus, when the initiative focused on projects that took place in public spaces, social media interaction on its own did not appear to be enough. The initiatives had a strong relationship with the physical space that they were working with. The interest in improving a common public space created ties that brought the group together. This was the case for the Organismo Parque Augusta, which strongly relied on social media but also on physical access to the park's terrain. In this specific case, the initiative used to meet in the park, but when they were deprived access to it this had a strong impact on the initiative. This shows how much the physical space plays a fundamental role in these initiatives.

[...] we have met weekly since 2013 [...] and we are still resisting. The park was illegally closed at the end of 2013. [...] and since it has been closed there has been less enthusiasm, because the area itself provides encouragement for our meetings, the peoples' articulation [...] it is the terrain itself that stimulates this. The meetings were always there, until 2013, but after this there was a weakening and some neglect, but we managed to reactivate start the meetings at the Roosevelt Square next to it. We had to organise ourselves in a nomadic way (Member of Organismo Parque Augusta).

This strong tie to the territory was repeatedly mentioned in all interviews. It seems fundamental to have a social connection with residents in the area where the initiatives are located. One initiative that had been formed by artists who were attempting to tackle different urban problems using art as a solution explained how they chose an area to work.

I think that is [...] we never go to a place like 'ah, let's take a look at the map and think: wow that place has a conflict and we need to work on it'. No, there is a network of affective attachments [...] that is, we go to a place because there are people we know there (Member of Bijari).

Nevertheless, the fragmented urban structure of São Paulo undermines the social connection between different groups, which have difficulties in overcoming the polarisation between the centre and the periphery. The social connections between initiatives in the city centre and the inhabitants of the periphery are at the level of functionality based on Sabatini's scale (2007). This issue was mentioned several times in 5 interviews. A member of a group based in the city centre working on the renewal of public stairways mentioned that despite their effort it was very difficult to start a project on the periphery, where they had only worked once:

It is easier to work where you already know the people, the collectives [...] Everything seems easier and simpler [...] so to get to a territory that you don't know, that has informal settlements, that has drug trafficking, that has many other forces at play that you don't know of [...] it is hard, it is very hard to work. Everyone from our organisation lives in the extended city centre [...] a bubble, right? No one is from the periphery (Member of Cidade Ativa).

Since social connections are one of the pillars of self-organised initiatives, the fragmentation pattern of São Paulo undermines the social connections between the centre and the periphery and in turn the social network of self-organised initiatives. The expansion of the area of action or attempts to undertake projects outside the extended city centre are much more difficult. In addition to the lack of social connection with residents on the periphery, as mentioned above by the Cidade Ativa member, mobility and safety were commonly mentioned as the main obstacles to undertaking work outside the city centre. Both problems were mentioned in all interviews. It is clear that the fragmentation in São Paulo, as described by Santos, is still directly influencing the range of areas in which these initiatives can work.

We have the wish to work on the periphery [...] we did some minor work there ... we had maybe two projects there [...] but to be honest, we work a lot in the city centre and in the west zone [...] it is where many of these urban and cultural interventions happen [...] Sometimes we try, we say 'Let's change our focus and go there', but the tendency [...] when we think about a project, we sit down and say 'Well, this project [...] where will we install it?' we always think about more central neighbourhoods. [...] we go to Pinheiros, to the Largo da Batata [...] I don't know, maybe we go the Ibirapuera Park, but it is still quite 
central. It is where we have more visibility, it is easier to access, it is also safer [...] there is that issue too. In the periphery you need to be better prepared. The periphery is a place we don't know well. We are from the middle class, there is a whole structure there [...] we are in our little world [...] you go to one of these neighbourhoods and you have to [...] well, we want and like it, it is also part of our work, but to be honest, it is more complicated (Member of Bela Rua).

Although this locational limitation of self-organised initiatives was repeatedly mentioned, a common positive point cited by all of the initiative members interviewed was the capacity of these initiatives to bring together a very diverse group of people. This is especially relevant in a country with striking inequality, and where there are many redevelopment projects underway to generate consumption and economic gain (Cortes, 2008). In this sense, the city of São Paulo has been more successful in generating places of consumption than places of diversity.

Some interventions by the municipal government have generated empty public spaces offering only functional integration between local inhabitants. This was the case for the Largo da Batata, a traditional square in São Paulo that was part of a major redevelopment project called 'Operação Faria Lima', occurring over the last 20 years. After the renovation of the square was completed, it was possible to observe that the project had focused much more on the transport aspect (a new tunnel, a metro stop and quicker access by car) than on the human scale. Although the redevelopment of the square was completed, it was left as a simple open paved space. There was limited interaction between the people 'using' the space, since the square was mainly seen as a commuter hub.

It was only after a self-organised initiative called 'A batata precisa de você' (The Batata Square needs you) started to redevelop the square that it became a diverse and lively space. The case of 'a batata precisa de você' is emblematic, not only because it was triggered by the relative failure of the public administration to create a vibrant urban environment for the local residents, but also because it was very successful in promoting social connections between groups that rarely interact. Even though the initiative had its operational limitations, it revealed how a self-organised initiative could bring together people with different socioeconomic profiles. Despite their social differences, they shared the common interest of having a pleasant urban space at their disposal. This perspective was also shared by all initiatives. The cases of Terreyro Coreográfico, which organises dance classes under viaducts to redevelop the area, and Organismo Parque Augusta's role in the management of the park were extremely symbolic in this respect.

For example, last year we had a 'festa junina' [a Brazilian folk festival]. And there were people from the neighbourhood, workers and middle-class people [...] there were real homeless people [...] also a transgender person who lives under this viaduct [...] there were some artists. It was crazy, everybody was dancing together [...] I thought it was beautiful to have this integration between people from such different groups (Member of Terreyro Coreográfico).

So [...] a lot of homeless people came and spent all these moments with us [...] many heavy drugs users were there. So, you could see old ladies [referring to the high-income local residents] giving detox herbal tea to the crack addicts to help them. There were some very thought-provoking relationships of affection [...] very powerful for a city like São Paulo (Member of Organismo Parque Augusta).

In this respect, based on Sabatini and Salcedo's integration framework, it was possible to observe the capacity of these self-organised initiatives to transform functional integration into symbolic and sometimes even community integration. Field observation of the 'Largo da Batata' confirmed the information collected from the interviews, which demonstrated that self-organised initiatives have the capacity to generate social connections even between extremely diverse groups. 


\section{Discussion and conclusions}

Based on the case of São Paulo, the influence of spatial fragmentation on the operations of self-organised initiatives revealed the following. Firstly, although initiatives rely on the virtual domain for communication, their activities are highly dependent on the physical context. The virtual environment, such as social media, proved to be an effective tool to spread the word about the initiatives' work and to get more participants involved. This capacity to self-organise using online tools for example seems to be similar to other cases, like pointed out by Kotus \& Hławka (2010). Nevertheless, the initiatives studied here were highly dependent on the availability of physical space. When access to the location of the initiative or the place they met were denied, the initiatives faced greater challenges in organising themselves. However, it was also interesting to observe that in the case of the Organismo Parque Augusta initiative, the connection with the physical space alone was not sufficient to attract new members. Moreover, some participants who already knew about the initiative because they had seen activities in their local context only became regular members after interaction with the group on social media. In this respect, the physical and virtual realms are connected and both are important to the initiatives' work.

Secondly, we found that the dichotomy between centre and periphery is still relevant, which refers to the dynamics already pointed out in Santos' work regarding fragmentation on the city of São Paulo (Santos, 1990). The polarisation of the city centre and the periphery is still apparent in the urban dynamics today. Furthermore, the interviews revealed that this polarised system has a strong negative influence on how initiatives operate. Although the initiatives repeatedly affirmed that they would like to expand their work to the periphery, the interviewees exposed the difficulty of taking their initiatives beyond their own local context in the city centre.

Based on the work of Ribeiro \& Ribeiro (2013), the peripheral neighbourhoods of São Paulo have a lower urban well-being and could benefit more from the work of these initiatives than the city centre. Nevertheless, those initiatives working in the city centre rarely managed to take their actions to the periphery. The interviews conducted in São Paulo showed that the lack of social connection with residents from the periphery added to logistical challenges, such as difficult access and the threat of violence, which were the main factors cited as obstacles to taking the initiatives beyond the extended city centre. Based on the framework of Sabatini and Salcedo, the lack of integration between inhabitants of the expanded city centre and the periphery confirms that they are mainly on the level of functional integration (Sabatini \& Salcedo, 2007). This lack of social connection with residents of peripheral neighbourhoods also had an effect on the snowball strategy used in this research, as all the initiatives contacted were based in the extended city centre of São Paulo. The research could be further broadened to understand the dynamics and limitations of initiatives in peripheral neighbourhoods and their connection with the city centre. Nevertheless, the negative effect of this polarised fragmentation is evident in the case of the self-organised initiatives studied here.

While constrained by the polarisation of the city of São Paulo, the self-organised initiatives demonstrated a great potential to promote encounters between people from diverse groups. This aspect was cited in all interviews and also witnessed in the field observations. The capacity to generate social connection between very distinct groups could be extremely helpful in overcoming spatial fragmentation in an unequal society. Using the framework of Sabatini \& Salcedo (2007) referred in the theoretical section, it was observed that the initiatives developed social ties that could be understood on the level of symbolic and community integration, while without them the only form of integration was merely at the functional level. The study showed that the intensification of the level of integration between the people participating in the initiatives can have a strong impact on the local social dynamics and particularly in the space where these initiatives occur. This was seen in the work of all 6 initiatives. The impact of a stronger social relationship between members of these initiatives on the space in which they work should thus be further studied. Rather than examining how fragmentation influenced these initiatives, it would be interesting to consider how these initiatives influence fragmentation itself by creating stronger social 
ties. For example, to what extent do these strongly socially connected self-organised groups break down this fragmentation logic, at least at the local level?

Thirdly, the case of São Paulo can serve as an example to other spatially fragmented cities of the world, but especially of the Global South. Self-organised initiatives can have a positive impact; however, as the results have shown, it is important to understand the fragmentation pattern of the city where such initiatives take place. Fragmentation can have a negative impact on how self-organisation initiatives work and this can vary depending on the fragmentation pattern of each city. In the case of Rio de Janeiro, for example, fragmentation does not have the same polarised dynamic of São Paulo. The scattered pattern of informal settlements in Rio de Janeiro suggests that fragmentation might be related to the topography of the city. In the case of Rio, it is not a horizontal division between centre and periphery but perhaps a vertical fragmentation between the low lying and the high lying neighbourhoods. Two contexts popularly known in Rio de Janeiro as 'asfalto', the affluent formal neighbourhoods, and 'morro', the slums and informal areas on the hills of the city.

Finally, in the case of São Paulo, public policies could be created to promote and replicate successful self-organised initiatives projects that go beyond their local context, break down this polarisation and develop social ties between participants of initiatives and residents of the peripheral neighbourhoods. The municipality, for example, could offer incentives or better conditions for institutions to operate in the suburbs where they are needed more. This could be done, for example, by connecting initiatives with the sub-municipalities of peripheral neighbourhoods, or organising workshops or capacity training programmes. Despite the challenges, the positive impact of self-organised initiatives in the city centre could be strategically used in peripheral areas. In the case of São Paulo, this shift in the role of urban planners towards the facilitation of social-spatial initiatives (Nunbogu et al., 2017) could be fruitful, with planners mediating the process of extending self-organised initiatives from the city centre to the periphery and breaking down the polarised fragmentation dynamic.

\section{References}

Angel, S., Parent, J., \& Civco, D. L. (2012). The fragmentation of urban landscapes: global evidence of a key attribute of the spatial structure of cities, 1990-2000. Environment and Urbanization, 24(1), 249-283.

http://dx.doi.org/10.1177/0956247811433536.

Ashby, W. R. (1947). Principles of the self-organizing dynamic system. The Journal of General Psychology, 37(2), 125-128. http://dx.doi.org/10.1080/00221309.1947.9918144. PMid:20270223.

Balbo, M., \& Navez-Bouchanine, F. (1995). Urban fragmentation as a research hypothesis: rabat-salé case study. Habitat International, 19(4), 571-582. http://dx.doi.org/10.1016/0197-3975(95)00008-4.

Caldeira, T. P. R. (2000). City of walls. Crime, segregation, and citizenship in São Paulo. Berkeley: University of California Press.

Cortes, J. M. G. (2008). Politicas do espaço. São Paulo: Senac Editora.

D’Ottaviano, M. C. L. (2008). Condomínios fechados na Região Metropolitana de São Paulo: fim do modelo centro rico versus periferia pobre? (Tese de doutorado). University of São Paulo, São Paulo.

http://dx.doi.org/10.11606/T.16.2008.tde-25032010-091246.

Dam, R. v., Eshuis, J., \& Aarts, N. (2009). Transition starts with people: self-organising communities ADM and Golf Residence Dronten. In K. Poppe, C. Termeer, \& M. Slingerland (Eds.), Transitions: towards sustainable agriculture and food chains in peri-urban areas (pp. 81-92). The Netherlands: Wageningen Academic Publishers.

Dramstad, W. E., Olson, J. D., \& Forman, R. T. T. (1996). Landscape ecology principles in landscape architecture and land-use planning. Washington: American Society of Landscape Architects.

Eigen, M. (1971). Molecular self-organization and the early stages of evolution. Quarterly Reviews of Biophysics, 4(2), 149-212. http://dx.doi.org/10.1017/S0033583500000627. PMid:5134461. 
Foerster, H., \& Zoepf, G. W. (1962). Principles of self-organisation. New York: Pergamon.

Haken, H. (1983). Synergetics: an introduction: nonequilibrium phase transitions and self-organization in physics, chemistry, and biology (3rd rev. and enl. ed.). New York: Springer.

Heylighen, F. (2008). Complexity and self-organization. In M. J. Bates \& M. N. Maack (Eds.), Encyclopedia of library and information sciences. Boca Raton: CRC Press.

Instituto Brasileiro de Geografia e Estatística - IBGE. (2010). Aglomerados subnormais: informações territoriais. Rio de Janeiro: IBGE. Retrieved in 2018, January 03, from

http://www.ibge.gov.br/home/presidencia/noticias/imprensa/ppts/00000015164811202013480105748802.pdf

Instituto Brasileiro de Geografia e Estatística - IBGE. (2015a). População presente e residente. Rio de Janeiro: IBGE. Retrieved in 2018, January 03, from

http://seriesestatisticas.ibge.gov.br/series.aspx $?$ no=10\&op=0\&vcodigo=CD90\&t=populacao-presente-residente

Instituto Brasileiro de Geografia e Estatística - IBGE. (2015b). Taxa de urbanização. Rio de Janeiro: IBGE. Retrieved in 2018, January 03, from

http://seriesestatisticas.ibge.gov.br/series.aspx?no=10\&op=0\&vcodigo=POP122\&t=taxa-urbanizacao

Kee, T., \& Miazzo, F. (2014). We own the city: enabling community practice in architecture and urban planning. Amsterdam: TrancityxValiz.

Kotus, J., \& Hławka, B. (2010). Urban neighbourhood communities organised on-line - A new form of selforganisation in the Polish city? Cities (London, England), 27(4), 204-214.

http://dx.doi.org/10.1016/j.cities.2009.12.010.

Kovacic, Z., \& Giampietro, M. (2016). Between theory and quantification: an integrated analysis of metabolic patterns of informal urban settlements. Energy Policy. http://dx.doi.org/10.1016/j.enpol.2016.06.047.

Lister, N. M., Brocki, M., \& Ament, R. (2015). Integrated adaptive design for wildlife movement under climate change. Frontiers in Ecology and the Environment, 13(9), 493-502. http://dx.doi.org/10.1890/150080.

Lydon, M., \& Garcia, A. (2015). Tactical urbanism. Washington: Island Press. http://dx.doi.org/10.5822/978-161091-567-0.

Maricato, E. (2011). O impasse da política urbana no Brasil. Petrópolis: Vozes.

Newman, L., Waldron, L., Dale, A., \& Carriere, K. (2008). Sustainable urban community development from the grassroots: challenges and opportunities in a pedestrian street initiative. Local Environment, 13(2), 129-139. http://dx.doi.org/10.1080/13549830701581879.

Nunbogu, A. M., Korah, P. I., Cobbinah, P. B., \& Poku-Boansi, M. (2017). Doing it 'ourselves': civic initiative and selfgovernance in spatial planning. Cities (London, England), 74, 32-41. https://doi.org/10.1016/j.cities.2017.10.022.

ORGANISMO PARQUE AUGUSTA - OPA. (2019). Retrieved in 2019, September 09, from

http://issuu.com/organismopa

Pessoa, I. M., Tasan-Kok, T., \& Altes, W. K. (2016). Brazilian urban porosity: treat or threat? Proceedings of the Institution of Civil Engineers. Urban Design and Planning, 169(2), 47-55. http://dx.doi.org/10.1680/udap.15.00009.

Portugali, J. (1999). Self-organization and the city. New York: Springer.

Rauws, W. (2016). Civic initiatives in urban development: self-governance versus self-organisation in planning practice. The Town Planning Review, 87(3), 339-361. http://dx.doi.org/10.3828/tpr.2016.23.

Ribeiro, L. C. Q., \& Ribeiro, M. G. (2013). Ibeu: índice de bem-estar urbano. Rio de Janeiro: Letra Capital.

Sabatini, F., \& Salcedo, R. (2007). Gated communities and the poor in Santiago, Chile: functional and symbolic integration in a context of aggressive capitalist colonization of lower-class areas. Housing Policy Debate, 18(3), 577-606. http://dx.doi.org/10.1080/10511482.2007.9521612.

Santos, M. (1990). Metrópole Corporativa Fragmentada: o caso de São Paulo. São Paulo: Nobel. 
Santos, M. (2009). Metrópole corporativa fragmentada. São Paulo: Universidade de São Paulo.

Santos, M., \& Dias, J. F. (1982). A urbanização desigual: a especificidade do fenômeno urbano em países subdesenvolvidos. Petrópolis: Editora Vozes.

Schmidt-Thome, K., Wallin, S., Laatikainen, T., Kangasoja, J., \& Kyttä, M. (2014). Exploring the use of PPGIS in selforganizing urban development: case softGIS in Pacific Beach. The Journal of Community Informatics. 10(3). Retrieved in 2018, January 03, from http://ci-journal.net/index.php/ciej/article/view/1080/1111

Swyngedouw, E., \& Moulaert, F. (2010). Can neighbourhoods save the city?: community development and social innovation. In F. Moulaert (Ed.), Regions and cities (pp. 219-234). New York: Routledge.

Tonkens, E. (2008). De bal bij de burger: burgerschap en publieke moraal in een pluriforme, dynamische samenleving. Amsterdam: Vossiuspers UvA. http://dx.doi.org/10.5117/9789056295370.

Villaça, F. F. F. (2011). São Paulo: segregação urbana e desigualdade. Estudos Avançados, 25(71), 37-58. http://dx.doi.org/10.1590/S0103-40142011000100004.

Wunsch, J. S. J. J. S. (2013). Analyzing self-organized local governance initiatives: are there insights for decentralization reforms? Public Administration and Development, 33(3), 221-235.

http://dx.doi.org/10.1002/pad.1652.

Editor: Fábio Duarte

Received: Jan. 03, 2018

Approved: Jan. 06, 2019 